\title{
Biological Potential of Semi-Purified Enterocin of Enterococcus sp. YT3 Against Selected Food Pathogens
}

\author{
CHARU KHANNA ${ }^{1}$, SHALINI SINGH ${ }^{1 *}$, MANISH VYAS ${ }^{2}$ and SUJATA DAS ${ }^{1}$ \\ 'Department of Microbiology, School of Bioengineering and Biosciences, Lovely Professional University, \\ Punjab, India-144411. \\ 2Department of Ayurvedic Pharmaceutical Sciences, School of Pharmaceutical Sciences, \\ Lovely Professional University, Punjab, India-144411. \\ *Corresponding author E-mail: shalinisingh.iit@gmail.com, shalini.singh@|pu.co.in
}

http://dx.doi.org/10.13005/ojc/350517

(Received: September 14, 2019; Accepted: October 31, 2019)

\begin{abstract}
The efforts for prevention of food borne illness and infections draw great attention, worldwide. Different methods, both physical as well as chemical, are commonly used for improving shelf life of food, but limited efficiency of physical methods, and potential health hazards associated with chemical methods, have brought biological processes in the limelight. One such natural, environment friendly, highly effective natural food preservants are, bacteriocins. Thus, there is a continuous need for better bacteriocin producers in the search for more effective bacteriocins than what are already available in the market. In the current study, food samples were collected from local market of Jalandhar, Punjab, and evaluated for bacteriocin producing Lactic acid bacteria. Enterococcus sp. YT3 was found to be the most efficient bacteriocin producer among the isolates, with higher bacteriocin activity exhibited by the given strain under optimized cultural conditions. The partially purified bacteriocin have molecular weight between $35 \mathrm{kDa} \& 48 \mathrm{kDa}$, possess $\mathrm{pH}(2-10)$ and thermal stability (even at $121^{\circ} \mathrm{C}$ for $20 \mathrm{~min}$ ), and exhibit antimicrobial activity against different bacteria (E. coli, P. aeruginosa, $S$. aureus, B. subtilis and L. monocytogenes). Future studies will focus on checking different food samples for real time evaluation of shelf life improvement.
\end{abstract}

Keywords: Enterococcus sp. YT3, Bacteriocin, Optimisation, Food pathogens, SDS-PAGE.

\section{INTRODUCTION}

Bacteriocins are the ribosomally synthesized anti-microbial peptides produce of some bacteria and are known to act against closely related microbes. Owing to such valuable biological potential, research has been focussed to isolate and characterize efficient bacteriocin producing organisms, which can further be utilized for large scale applications in health and food industry ${ }^{1}$. Lactic acid bacteria (LAB) represent a group of important bacteriocin producers, commonly associated with various food substances. Food sources like, meat and meat products, milk and milk products, are rich in microbial diversity including, Lactic acid bacteria $(L A B)$. The bacteriocins, from $L A B$ strains are considered to be the most eminent and natural alternatives/supplements to some classical food

This is an Open Access article licensed under a Creative Commons license: Attribution 4.0 International (CC- BY). Published by Oriental Scientific Publishing Company @ 2018

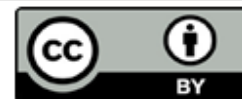


preservation techniques such as, drying and deep freezing, and use of artificial chemical preservatives. Examples include, meat and meat products where, benzoic acid and sorbic acid are often used for the purpose of preservation ${ }^{2,3,4}$. Nisin, a bacteriocin of Lactococcus lactis, is one example of FDA approved food preservative ${ }^{1}$, which show exceptional efficacy as a natural food preservative. Still, certain limitations with applications of nisin such as, narrow spectrum of antimicrobial activity, inactivity at higher $\mathrm{pH}$, non-uniform distribution, interference by food components such as phospholipids, and emergence of nisin resistant microbial strains ${ }^{1,5}$, has kindled the need to look for its alternatives.

The bacteriocins of lactic acid bacteria such as, Lactococcus, Lactobacillus, and Enterococcus, possess wide range of biological potentials ${ }^{3,6}$, but their real time usage in health and food industrial sector, are still limited. The present study attempts for the isolation and screening of bacteriocin producing LAB strains, possessing efficient antimicrobial potential that can further be explored as a natural and powerful food preservative as such bacteriocins are the demand of time as food borne diseases are of major concern, globally?

\section{MATERIAL AND METHODS}

\section{Procurement and Maintenance of cultures}

Five indicator bacterial strains, E. coli, Pseudomonas aeruginosa, Listeria monocytogenes, Staphylococcus aureus, Bacillus subtilis were used in the study. The lyophilised cultures of E. coli MTCC1687 and L. monocytogenes MTCC1143 were purchased from Microbial Type Culture Collection Centre (MTCC), Chandigarh, Punjab, and revived in Nutrient broth and Brain Heart Infusion (BHI) broth, respectively. Glycerol stock of $S$. aureus, B. subtilis and $P$. aeruginosa were obtained from laboratory of Microbiology, Department of Microbiology, Lovely Professional University, Punjab. All bacterial cultures were inoculated in Nutrient Broth, incubated at $37^{\circ} \mathrm{C}$ for $24 \mathrm{~h}$, and then, streaked onto appropriate nutrient media Mannitol Salt Agar (S. aureus), Nutrient agar (S. aureus) and Cetrimide agar ( $P$. aeruginosa), respectively, and subsequently incubated at $37^{\circ} \mathrm{C}$ for $24 \mathrm{~h}$ (Table 1). The cultured plates/slants, so obtained, were further stored under refrigerated conditions $\left(4 \pm 2^{\circ} \mathrm{C}\right)$. For long term preservation,
$1 \mathrm{ml}$ of bacterial culture, individually, was added to $1 \mathrm{ml}$ sterilised $30 \%$ glycerol aseptically, in $2 \mathrm{ml}$ cryo vials. All the vials were then stored at $-20^{\circ} \mathrm{C}$.

\section{Collection of food samples for bacteriocin producers}

Different samples of milk \& milk products, salami and raw chicken, from local shops, and homemade curd samples, from local residents of Jalandhar, Punjab, India, were collected and thereafter kept in sterile plastic bags safely. The obtained samples were transported to Microbiology laboratory, Lovely Professional University, Punjab, India, over ice in an icebox, and processed immediately.

\section{Isolation and screening of lactic acid bacteria from food samples \\ One gram, each of raw chicken and} salami, were macerated and homogenized in $10 \mathrm{ml}$ of double distilled sterilized water. $1 \mathrm{ml}$ of milk and homogenised curd samples were added in $9 \mathrm{ml}$ of double distilled sterilized water and individual stock samples, thus prepared. All the samples were diluted serially, spread plated on Bile Aesculine Azide Agar, aseptically, followed by incubation at $37^{\circ} \mathrm{C}$ for 24 hours. Bacterial colonies so obtained, were studied for morphological (colour, shape and texture of colonies), subjected to microscopic (Gram's stain reaction, bacterial cell shape and arrangement) examination, and catalase test for selected bacterial colonies $^{8,9,10,11}$. Thereafter, the obtained isolates were studied for the different biochemical screening tests as depicted in Table 3.

\section{Preliminary screening of strains for Bacteriocin production}

Selected isolates, as obtained above, were screened for bacteriocin production. 2-3 colonies were randomly picked from pure cultures of the selected bacterial isolates, and transferred aseptically to $10 \mathrm{ml}$ seed culture media (MRS broth). After incubating for the period of $24 \mathrm{~h}$ at $37^{\circ} \mathrm{C}$, the obtained cultured broths were centrifuged at 10,000 rpm for 10 minutes. The cell free supernatant (CFS) was separated from pellets. $100 \mu$ l of CFS was added into wells $(8 \mathrm{~mm})$ on sterilised Muller Hinton Agar media plates, having lawn cultures of different test organisms (E. coli, P. aeruginosa, L. monocytogenes, S. aureus and B. subtilis). The plates were then incubated for $24 \mathrm{~h}$ at $37^{\circ} \mathrm{C}$. Eventually, the zone of 
inhibition (ZOI), in $\mathrm{mm}$, was measured for selected LAB strains, against selected pathogens ${ }^{12,13}$. Amongst the six isolates, the isolate exhibiting antimicrobial activity against maximum number of indicator strains was selected for the further study. Amongst the five test organisms, the strain exhibiting maximum zone was selected as indicator strain for the purpose of optimisation.

Further, the CFS of the selected isolate was checked to confirm the source of antimicrobial activity by subjecting portions of CFS adjusted to $\mathrm{pH} 6.5$ and treatment with an enzyme, catalase, $(300 \mathrm{U} / \mathrm{ml})$. The antimicrobial activity was then determined by well diffusion technique ${ }^{14,15,16}$.

\section{Taxonomic analysis of the selected strain}

Further, the selected bacterial isolate was grown on sterilised Bile aesculine azide agar (BAA) agar slants, and then sent to Chromous Biotech, Bangalore, for $16 \mathrm{~S}$ ribosomal DNA sequencing. The genomic DNA ( 1.5kb) was isolated, followed by amplification of the obtained fragment with PCR polymerase. The product, thus obtained, was sequenced bi-directionally, obtained data aligned \& then analysed for its closest neighbour's identification ${ }^{17}$.

\section{Optimisation of Bacteriocin production by test isolate}

Each $10 \mathrm{ml}$ of MRS broth was poured in plugged glass test tubes followed by sterilisation at $121^{\circ} \mathrm{C}$ with $15 \mathrm{lbs}$. pressure, and the cooled tubes inoculated with $100 \mu \mathrm{l}$ of fresh overnight cultured test isolate. After desired incubation (12 h, $24 \mathrm{~h}$, $36 \mathrm{~h}, 48 \mathrm{~h}, 66 \mathrm{~h}, 72 \mathrm{~h}$ ), samples were drawn and CFS obtained. Subsequently, wells $(8 \mathrm{~mm})$ were cut on sterilized MRS agar media plates, already swabbed with test organisms, to prepare a thick lawn culture of each indicator strain. The obtained CFS was then added in each well, incubated at $37^{\circ} \mathrm{C}$ and ZOI observed after 24 hours. Inhibitory zones were then recorded horizontally and vertically, and reported as an average of the two ${ }^{14,15,16}$. Appropriate controls included the un-inoculated sterilised MRS broth exposed to similar conditions and tested for anti-microbial potential.

Similarly, the inoculated MRS broth samples were incubated at different incubation temperatures $\left(25^{\circ} \mathrm{C}, 30^{\circ} \mathrm{C}, 37^{\circ} \mathrm{C}, 45^{\circ} \mathrm{C}\right.$ and $\left.50^{\circ} \mathrm{C}\right)$ so as to analyse influence of incubation temperature on bacteriocin production. The activity of CFS for test isolate thus, obtained against indicator strain, was determined in terms of ZOI ( $\mathrm{mm})$ as explained above $\mathrm{e}^{14,15,16}$. Appropriate controls were prepared as above and similarly tested for anti-microbial potential.

The effect of $\mathrm{pH}$, on bacteriocin production, was then determined by adjusting the $\mathrm{pH}$ of MRS broth (initial media) to 4.5, 5.0, 5.5, 6.0, 6.5, 7.0 using $1 \mathrm{~N} \mathrm{HCl}$ or $1 \mathrm{~N} \mathrm{NaOH}$ and incubating the samples for optimised time duration, and temperature. The anti-microbial potential was subsequently determined as already explained ${ }^{14,15,16}$. Appropriate controls included the un-inoculated sterilised MRS broth.

Thereafter, the MRS broth has been supplemented with different sugars (glucose, fructose, lactose, and sucrose) with variable concentration (1-5\%) and nitrogen sources, both organic (tryptone, beef extract), at variable concentration (1-5\%) as well inorganic (triammonium citrate, ammonium sulphate), at different concentration ranging from $0.1-0.5 \%$. The medium was adjusted to optimised $\mathrm{pH}$, sterilised, test isolate inoculated and allowed to grow under optimized conditions of time and temperature. Thereafter, the bacteriocin activity was determined as already explained. The appropriate control in the study included MRS broth media adjusted to $\mathrm{pH} 6$, without any supplemented sugar or nitrogen source incubated under optimised conditions.

\section{Purification of Bacteriocin produced under optimized conditions by test isolate}

$100 \mathrm{ml}$ MRS broth, taken in $250 \mathrm{ml}$ conical flask, supplemented with best simple sugar source and nitrogen source, was adjusted to $\mathrm{pH} 6.0$, and were autoclaved. The sterile flasks were then inoculated with $1 \mathrm{ml}$ of fresh overnight cultured isolate and incubated at optimised time and temperature. The CFS thus obtained, as above, was subjected to $30 \%-80 \%$ ammonium sulphate precipitation, by its slow addition in the beaker using a magnetic stirrer (at $20^{\circ} \mathrm{C}$ ) for 2 hour. The obtained solutions were centrifuged at $10,000 \mathrm{rpm}$ for nearly $20 \mathrm{~min}$ and pellets were dissolved with $0.02 \mathrm{M}$ potassium phosphate buffer ( $\mathrm{pH} 6.5 ; 0.5 \%$ the volume of CFS used) after discarding the supernatant and the anti-microbial potential was analysed by well diffusion technique. 
Finally $25 \mathrm{ml}$ of partially purified bacteriocin/ bacteriocin like substance was prepared, filter sterilised and stored in a $50 \mathrm{ml}$ sterilised capped glass bottle at $-20^{\circ} \mathrm{C}$ for further use $\mathrm{e}^{14,15,16,17}$.

\section{Influence of temperature, $\mathrm{pH}$ and enzymes on} biological potential

Effect of temperature: $5 \mathrm{ml}$ cell free supernatant (CFS), obtained under optimised cultural conditions, was taken in different $10 \mathrm{ml}$ test tubes. Each test tube was exposed for $20 \mathrm{~min}$ to different temperatures $\left(37^{\circ} \mathrm{C}, 60^{\circ} \mathrm{C}, 80^{\circ} \mathrm{C}\right.$, and $\left.100^{\circ} \mathrm{C}\right)$, and cooled to room temperature. One set was autoclaved at $121^{\circ} \mathrm{C}$ for $20 \mathrm{~min}$, cooled, and followed by filter sterilisation. The treated CFS sample was collected and residual antimicrobial activity was subsequently checked against different the indicator strain, as explained. Similar treatment was given to appropriate controls (Untreated CFS) $)^{14,15,16}$.

Effect of pH: Each $5 \mathrm{ml} \mathrm{CFS} \mathrm{obtained} \mathrm{with}$ optimised conditions was taken in $10 \mathrm{ml}$ test tubes and was adjusted to different $\mathrm{pH}(2,4,5,9$ and 10) with $1 \mathrm{~N} \mathrm{HCl}$ or $1 \mathrm{~N} \mathrm{NaOH}$. It was then incubated at $37^{\circ} \mathrm{C}$ for $2 \mathrm{~h}$ and filter sterilised. The residual bacteriocin potential was studied by well diffusion assay and compared with that of controls (untreated CFS) ${ }^{14,15,16}$.

Effect of enzymes: Pepsin, Proteinase- K, Trypsin, $\alpha$-Amylase and Lysozyme were added to sterile test tubes, each containing, $300 \mu$ l of PPB. The final concentration of each sample was maintained at $1 \mathrm{mg} / \mathrm{ml}$, and all the treated samples were incubated at $37^{\circ} \mathrm{C}$ for 2 hours. Thereafter, the samples were filter sterilised, and residual antimicrobial activity determined ${ }^{14,15,16}$.

\section{Determination of protein molecular weight}

The partially purified bacteriocin/bacteriocin like substance was subsequently subjected to SDSPAGE for protein molecular weight determination ${ }^{18,19}$. $10 \mu \mathrm{l}$ of the sample and $5 \mu \mathrm{l}$ of the prestained protein marker with broad range were loaded in the well, in a agarose gel. The experiment was carried at 100 volts and 10mA till the dye front reached $0.5 \mathrm{~cm}$ above the lower level of the stacking gel. Thereafter, the gel was removed carefully and was added in the tray containing $50 \mathrm{ml}$ of the staining solution overnight. The gel was then washed with distilled water and added to the destaining solution with moderate shaking till the clear bands were observed. The bands of the samples were matched with that of the marker.

\section{Antimicrobial potential towards selected food pathogens}

Finally, the antimicrobial activity of semi purified bacteriocin, using different dilutions prepared in $0.02 \mathrm{M}$ acetic acid, was analysed against the five, common food borne pathogens (E. coli, P. aeruginosa, L. monocytogenes, S. aureus and B. subtilis) ${ }^{12,13}$.

\section{Statistical analysis}

All the experimental have been performed with triplication. The results have been expressed in mean \pm standard deviation (SD). The software, Microsoft Office in Excel 2010, have been used to calculate the same.

Table 1: Bacterial cultures used as indicator strains

\begin{tabular}{|c|c|c|c|c|}
\hline Bacterial strain & Source & Incubation Temperature & Growth Media & Application \\
\hline E. coli (MTCC1687) & MTCC, Chandigarh & $37^{\circ} \mathrm{C}$ & Nutrient Broth/ MacConkey agar & Indicator strain \\
\hline P. aeruginosa (MTCC4673) & $\mathrm{ML}, \mathrm{LPU}^{\star}$ & $37^{\circ} \mathrm{C}$ & Nutrient Broth/ Cetrimide Agar & Indicator strain \\
\hline S. aureus (MTCC96) & ML, LPU* & $37^{\circ} \mathrm{C}$ & Nutrient Broth/ Mannitol Salt Agar & Indicator strain \\
\hline B. subtilis (MTCC 121) & $\mathrm{ML}, \mathrm{LPU}{ }^{*}$ & $37^{\circ} \mathrm{C}$ & Nutrient Broth/ Nutrient Agar & Indicator strain \\
\hline L. monocytogenes (MTCC1143) & MTCC, Chandigarh & $37^{\circ} \mathrm{C}$ & & \\
\hline BHI Broth/Agar & Indicator strain & & & \\
\hline
\end{tabular}

MTCC: Microbial Type Culture Collection, Chandigarh, Punjab, India

ML, LPU*: Microbiology Laboratory, Department of Microbiology, Lovely Professional University, India

\section{RESULTS AND DISCUSSION}

\section{Procurement and Maintenance of cultures}

The different bacterial strains were cultured on different nutrient media as indicated in Table 1 and were used as the indicator strains for this study.
Isolation and screening of lactic acid bacteria from food samples

Of the total 680 isolates obtained from different food samples (Table 2), 6 isolates (I1-16) were determined as catalase negative (Table 3). The selected isolates has been observed to be 
Gram-positive, catalase negative, and presented typical pin pointed colonies on MRS agar medium. Isolate 1, 4, 5 and 6 were cocci, occurring in pairs, tetrads or as short chains while the other two isolates (I2 and I3) were rod shaped, occurring short chains (Table 4).

Table 2: Collection of samples for bacteriocin producers

\begin{tabular}{cccc}
\hline S. No & Number of Sample & Place of purchase & Number of samples \\
\hline 1 & Pasteurised milk & Local shop, Jalandhar, India & 5 \\
2 & Homemade Curd & Local residents, Jalandhar, India & 2 \\
3 & Raw Chicken & Easy day store, Jalandhar, India & 5 \\
4 & Salami & Local shop, Jalandhar, India & 5 \\
\hline
\end{tabular}

Table 3: Isolation and screening of bacteria from food samples

\begin{tabular}{lccll}
\hline Bacterial strain & Source & Incubation Temperature & Growth Media & Application \\
\hline Isolate 1(I1) & Milk & $37^{\circ} \mathrm{C}$ & MRS Broth/Agar & Bacteriocin production \\
Isolate 2(I2) & Milk & $37^{\circ} \mathrm{C}$ & MRS Broth/Agar & Bacteriocin production \\
Isolate 3(I3) & Raw chicken & $37^{\circ} \mathrm{C}$ & MRS Broth/Agar & Bacteriocin production \\
Isolate 4(I4) & Salami & $37^{\circ} \mathrm{C}$ & MRS Broth/Agar & Bacteriocin production \\
Isolate 5(I5) & Salami & $37^{\circ} \mathrm{C}$ & MRS Broth/Agar & Bacteriocin production \\
Isolate 6(I6) & Curd & $37^{\circ} \mathrm{C}$ & MRS Broth/Agar & Bacteriocin production \\
\hline
\end{tabular}

11-16: Designation of selected LAB isolates from different food samples

Table 4: Preliminary morphological and microscopical characterisation of bacterial isolates

\begin{tabular}{|c|c|c|c|c|c|c|c|}
\hline \multirow{2}{*}{\multicolumn{2}{|c|}{ Microbial Characteristics }} & \multicolumn{6}{|c|}{ Lactic acid bacterial (LAB) isolates } \\
\hline & & 11 & 12 & 13 & 14 & 15 & 16 \\
\hline & Colour & Cream & Greyish & Greyish & Greyish & Greyish & Greyish \\
\hline \multirow[t]{2}{*}{ Colony } & $\begin{array}{l}\text { Shape } \\
\text { Texture }\end{array}$ & $\begin{array}{l}\text { Pin pointed, } \\
\text { convex Smooth }\end{array}$ & $\begin{array}{c}\text { Pin pointed, } \\
\text { convex Smooth }\end{array}$ & $\begin{array}{c}\text { Pin pointed, } \\
\text { convex Smooth }\end{array}$ & $\begin{array}{c}\text { Pin pointed, } \\
\text { convex Smooth }\end{array}$ & $\begin{array}{c}\text { Pin pointed, } \\
\text { convex Smooth }\end{array}$ & $\begin{array}{c}\text { Pin pointed, } \\
\text { convex Smooth }\end{array}$ \\
\hline & Gram staining & + & + & + & + & + & + \\
\hline \multirow[t]{2}{*}{ Microscopy } & Shape of microbe & Coccus & Bacillus & Bacillus & Coccus & Coccus & Coccus \\
\hline & Cell Arrangement & $\begin{array}{l}\text { Diplococcus } \\
\text { or tetrads }\end{array}$ & Short chains & Short chains & Singly or in pairs & Diplococcus & $\begin{array}{l}\text { Short chains } \\
\text { or in pairs }\end{array}$ \\
\hline Catalase test & - & - & - & - & - & - & \\
\hline
\end{tabular}

+: Positive; - - Negative

11-16: LAB isolates obtained from food samples

These six isolates were further studied for preliminary characterization (Table 5). None of the isolate could produce ammonia in urease test. All the isolates resulted negative for Vogue's Prausker and tryptophan test. Only isolate 1 was able to utilise citrate as source of carbon as resulted in citrate utilisation test. All isolates were determined for fermenting wide range of sugars. Selected strains exhibited growth on different nutritional media. Of the six isolated strains, Isolate 6 was determined the growth in MRS broth with $6.5 \%$ $\mathrm{NaCl}$ along with all different range of temperatures tested $\left(25^{\circ} \mathrm{C}\right.$ to $45^{\circ} \mathrm{C}$; Table 5$)$.

\section{Preliminary screening of bacterial isolates for} Bacteriocin production

Amongst the six isolates, selected on the basis of morphological, microscopic and biochemical characters, two (I5 and 16) exhibited antagonistic activity towards the test indicator strains (Table 6). While CFS of 16 was effective against all tested pathogens, 15 was effective against $S$. aureus and $B$. subtilis only. Hence isolate 6 , sourced from homemade curd, has been selected for further study. Since maximum activity revealed by CFS of isolate 6 was against $B$. subtilis, hence it was chosen as the indicator test organism for the further study. Investigations on CFS obtained from 16 (Table 7), when adjusted to $\mathrm{pH} 6.5$ revealed no loss of antibacterial activity against $B$. subtilis. The lactic acid bacteria are potent in producing organic acids such as acetic acid, lactic acid, and propionic acid which reduces the $\mathrm{pH}$ of solution which may be the cause of antibacterial nature of CFS ${ }^{12,20}$. 
Table 5: Biochemical analysis of bacterial isolates under study

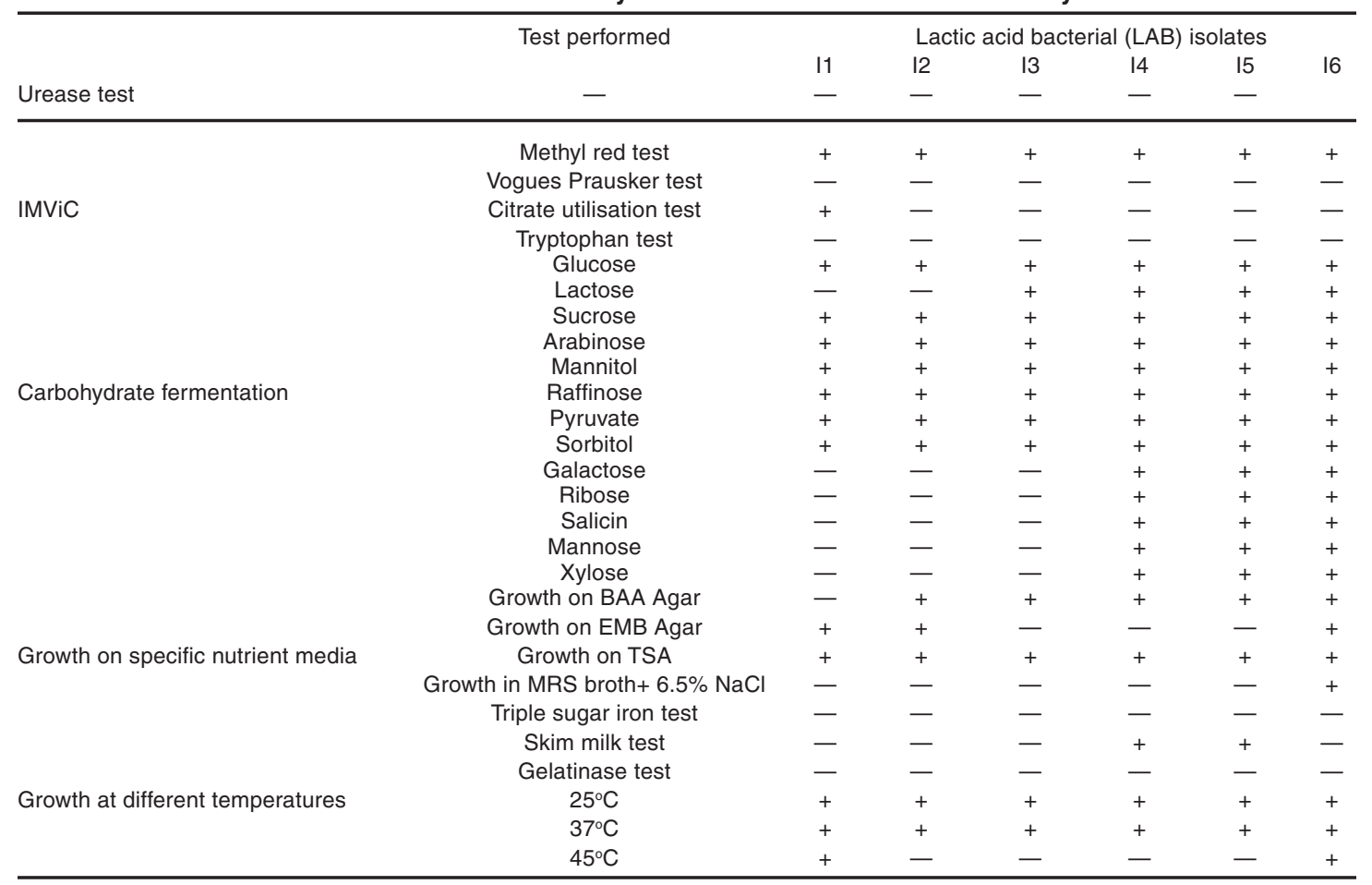

+: Positive activity; - - Negative activity

11-16: LAB isolates obtained from food samples

Table 6: Antimicrobial activity of CFS of isolates on test organisms

\begin{tabular}{cccccc}
\hline CFS of Isolate & \multicolumn{5}{c}{ Indicator test bacterial strains } \\
& E. coli & P. aeruginosa & S. aureus & B. subtilis & L. monocytogenes \\
\hline I 1 & - & - & - & - & - \\
I 2 & - & - & - & - & - \\
I 3 & - & - & - & - & - \\
I & - & - & - & - & - \\
I5 & - & - & + & + & + \\
I 6 & + & + & + & ++ & + \\
\hline
\end{tabular}

- For antibacterial analysis: Well- Diffusion Method (Well size: $8 \mathrm{~mm}$ ); Amount of sample used: 100 $\mathrm{ll}$; Incubation period: $24 \mathrm{~h}$, Incubation temp: $37^{\circ} \mathrm{C}$; Media used: Muller Hinton Agar (Himedia); $\mathrm{pH}$ : 7.3 \pm 0.1 , For L. monocytogenes: Listeria selective agar; $\mathrm{pH}: 7.3 \pm 0.2$.

$\bullet+$ : Positive activity; -: Negative activity

Table 7: Preliminary characterisation of Cell free supernatant to ensure the presence of bacteriocin

\begin{tabular}{ccc}
\hline S. No & Samples & \multicolumn{2}{c}{ Antibacterial potential of isolate 6 } \\
\hline 1 & CFS (Control) & ++ \\
2 & CFS adjusted to pH 6.5 & ++ \\
3 & CFS treated with catalase & ++ \\
\hline
\end{tabular}

-Antibacterial analysis: Well- Diffusion Method (Well size, $\mathrm{mm}: 8$ ); Amount of sample used: $100 \mu \mathrm{l}$; Incubation period: $24 \mathrm{~h}$; Incubation temp: $37^{\circ} \mathrm{C}$; Media used: Muller Hinton Agar; $\mathrm{pH}: 7.3 \pm 0.1$

- Indicator strain: B. subtilis;

- + : Zone of inhibition present

The obtained CFS, when subjected to catalase test showed no loss in antimicrobial activity. Some lactic acid bacteria yield hydrogen peroxide which potentiates them for antibacterial activity. Catalase causes the breakdown of hydrogen peroxide into water and oxygen ${ }^{21,22}$.

The results indicate that the biological potential of the selected strain was due to bacteriocin/ bacteriocin like substance in the supernatant, and not because of organic acids/hydrogen peroxide produced by the test organisms.

\section{Taxonomic analysis of the selected strain}

$16 S$ ribosomal DNA sequencing revealed bacterial isolate 16 to be an Enterococcus sp., which was designated as Enterococcus sp. YT3 for 
future reference. The closest homologue suggested were Enterococcus gallinarum strain 46W and
Enterococcus casseliflavus strain SBMAX24 and has been presented in the phylogenetic tree (Figure 1).

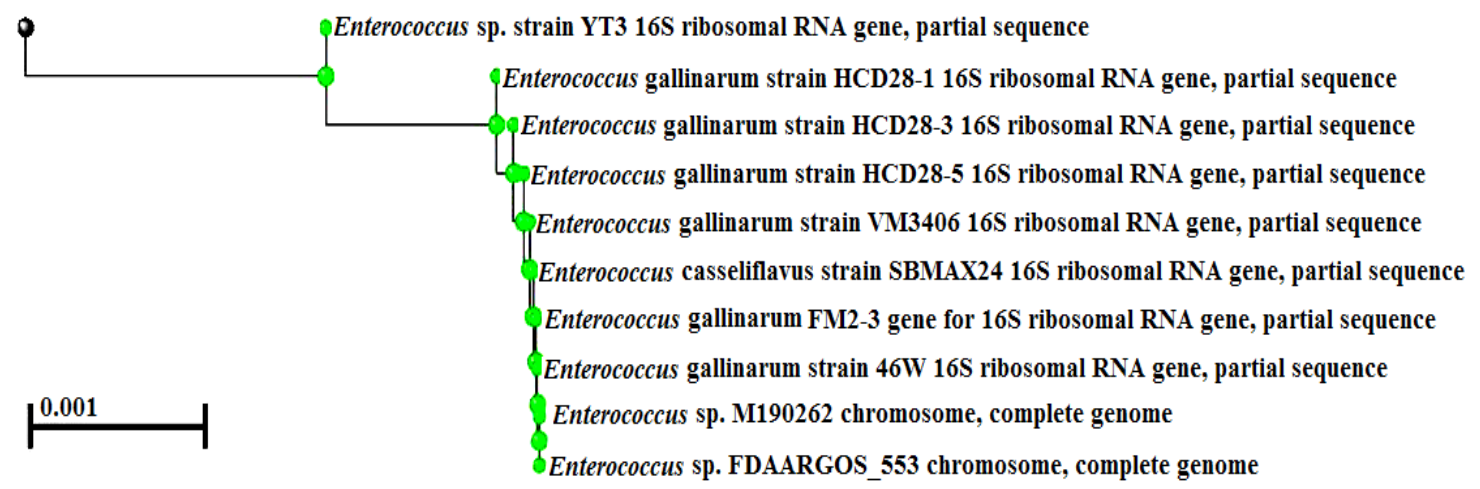

Fig. 1. Phylogenetic tree for Enterococcus sp. YT3 (16S ribosomal RNA gene, partial sequencing)

Optimisation of Bacteriocin production by test isolate

As shown in Table 8, the test strain, exhibited highest antimicrobial activity against the obtained CFS when kept for $48 \mathrm{~h}$ of incubation time, after which, there was a loss of $9.8 \%$ in activity, in comparison to the highest achieved. Gradual activity loss might be because of proteolytic degradation by proteases or due to adsorption of antimicrobial substances by the producer cells from their surface ${ }^{21,22}$. Some studies have been conducted where incubation has been done for $48 \mathrm{~h}$ for bacteriocin production ${ }^{23,24}$.

On evaluating the influence of incubation temperature on antimicrobial activity, the largest zone of inhibition $(27 \pm 0.8 \mathrm{~mm})$ was obtained for an incubation temperature of $37^{\circ} \mathrm{C}$ for $48 \mathrm{~h}$ of incubation time (Table 8 ). Similar reports on different species of Enterococcus, also mention best incubation temperature of $37^{\circ} \mathrm{C}^{16,25,26}$ for bacteriocin production.

Table 8: Influence of time, temperature and $\mathrm{pH}$ on the bacteriocin production

\begin{tabular}{cccccc}
\hline Time $(\mathrm{h})$ & ZOI $(\mathrm{mm})$ & Temp $\left({ }^{\circ} \mathrm{C}\right)$ & ZOI $(\mathrm{mm})$ & $\mathrm{pH}$ of media & ZOI $(\mathrm{mm})$ \\
\hline 12 & $20.7 \pm 0.9$ & 25 & $20.7 \pm 0.9$ & 4.5 & $24.6 \pm 0.9$ \\
24 & $22.7 \pm 0.9$ & 30 & $22.7 \pm 0.9$ & 5 & $25.6 \pm 0.9$ \\
36 & $25.3 \pm 0.4$ & 37 & $27 \pm 0.8$ & 5.5 & $26.3 \pm 0.5$ \\
48 & $27 \pm 0$ & 45 & $25.3 \pm 0.4$ & 6.0 & $28 \pm 1.6$ \\
66 & $25 \pm 0$ & 50 & $23 \pm 0.5$ & 6.5 & $26.7 \pm 0.9$ \\
72 & $23 \pm 0.5$ & - & - & 7.0 & $23.3 \pm 0.5$ \\
\hline
\end{tabular}

- During time optimisation: Media used: MRS broth; Incubation temp: $37^{\circ} \mathrm{C} ; \mathrm{pH}: 6.5 \pm 0.2$

- During Temperature optimisation: Media used: MRS broth; Incubation time: $48 \mathrm{~h} ; \mathrm{pH}: 6.5 \pm 0.2$

- During pH optimisation: Media used: MRS broth; Incubation time: $48 \mathrm{~h}$; Incubation temp: $37^{\circ} \mathrm{C}$

- Antibacterial analysis: Well-Diffusion Method (Well size, mm: 8); Amount of sample used: $100 \mu$ l;

Incubation period: $24 \mathrm{~h}$; Incubation temp: $37^{\circ} \mathrm{C}$; Media used: Muller Hinton Agar; $\mathrm{pH}: 7.3 \pm 0.1$

- Indicator strain: B. subtilis

Enterococcus sp. YT3 yielded highest activity for a medium $\mathrm{pH} 6.0$, with a zone of inhibition of $28 \mathrm{~mm}$ which was $5.7 \mathrm{~mm}$ larger than the smallest zone observed. The variation in zone size, illustrates the effect of $\mathrm{pH}$ on bacteriocin production. The metabolism of $L A B$ strains, their growth along with bacteriocin production is significantly affected by the medium $\mathrm{pH}$ and affecting cell aggregation, bacteriocin absorption and its proteolytic degradation. These antimicrobial peptides are produced at some specific range of $\mathrm{pH}$ which otherwise controls the enzymatic reactions happening in the cells. Sometimes at low $\mathrm{pH}$, due to accumulation of acids, the cell growth stops and so does bacteriocin production. $\mathrm{pH}$ may also regulate the expression of various biosynthetic genes, where slower growth rate enhances the bacteriocin production.

The acidified media during the process of fermentation may also affect the protein solubility 
along with polypeptide hydrolysis ${ }^{27,28}$. Similar results have been found in the literature where maximum activity has been confirmed by the LAB when initial $\mathrm{pH}$ was adjusted to $\mathrm{pH} 6^{25,26,29}$.

Fructose, at a concentration of $2 \%$ was determined to be the most influential carbon source as it yielded the highest production of bacteriocin, as compared to glucose, lactose, sucrose and the control (Table 9). Similar observations have been found in the studies by where Leuconostoc mesenteroides E131, Lactococcus lactis subsp. lactis HV219 and Lactobacillus sp. MSU3IR was found to yield high bacteriocin activity in fructose supplemented MRS broth ${ }^{11,30,31}$.

Table 9: The influence of different sugar and nitrogen supplemented in initial media (MRS broth) on the bacteriocin/bacteriocin like substance production

\begin{tabular}{lcc}
\hline Sugar & $\begin{array}{c}\text { Zone of inhibition }(\mathrm{mm}) \\
\text { of Bacillus subtilis }\end{array}$ \\
\hline Glucose & $1 \%$ & $21 \pm 0.8$ \\
& $2 \%$ & $24.7 \pm 0.9$ \\
& $3 \%$ & $23.3 \pm 1.9$ \\
Lactose & $4 \%$ & $22.7 \pm 0.9$ \\
& $5 \%$ & $22.3 \pm 1.9$ \\
& $1 \%$ & $25.3 \pm 0.5$ \\
Fructose & $2 \%$ & $25 \pm 0.8$ \\
& $3 \%$ & $24.7 \pm 0.9$ \\
& $4 \%$ & $24.3 \pm 0.5$ \\
& $5 \%$ & $22.6 \pm 1.7$ \\
Sucrose & $1 \%$ & $24.3 \pm 1.7$ \\
& $2 \%$ & $29 \pm 0.8$ \\
& $3 \%$ & $25.7 \pm 0.5$ \\
& $4 \%$ & $25 \pm 1.6$ \\
& $5 \%$ & $24 \pm 1.4$ \\
Control & $1 \%$ & $23.3 \pm 0.5$ \\
\hline
\end{tabular}

- For bacteriocin/bacteriocin like production: Incubation period: 48 h,; pH: 6; Incubation temp: $37^{\circ} \mathrm{C}$.

- Sugars supplemented in initial media (MRS broth, already possessing $2 \%$ Dextrose).

- Control: CFS of organism grown in initial media without any additional sugar.

- Antibacterial analysis: Well-Diffusion Method (Well size, mm: 8); Amount of sample used: $100 \mu \mathrm{l}$; Incubation period: $24 \mathrm{~h}$; Incubation temp: $37^{\circ} \mathrm{C}$; Media used: Muller Hinton Agar; $\mathrm{pH}$ : 7.3 \pm 0.1

- Indicator strain: $B$. subtilis

Purification of Bacteriocin produced under optimized conditions by test isolate

The bacteriocins/bacteriocin like substance
Tryptone, at a concentration of $4 \%$, supplemented in basal MRS media, yielded antimicrobial activity (Table 10). Nitrogen sources are required to synthesize proteins and nucleic acids. Organic sources such as, tryptone, yeast extract and beef extract are rich sources of vitamins, amino acids and minerals, which enhance the cell growth and bacteriocin production. Interestingly, inorganic nitrogen sources have showed conflicting results where both decrease as well as increase bacterial growth and/or bacteriocin production ${ }^{11,27}$. Tryptone has registered higher production of bacteriocin in Lactobacillus plantarum AMA-K and Lactococcus lactis too, in comparison to un-supplemented media $^{13,30,31}$.

Table 10: Influence of different nitrogen source supplemented in initial media (MRS broth) on the bacteriocin/bacteriocin like production

\begin{tabular}{|c|c|c|c|}
\hline & \multicolumn{2}{|c|}{ Nitrogen source } & \multirow{2}{*}{$\frac{\text { Zone of inhibition }(\mathrm{mm})}{23.3 \pm 0.5}$} \\
\hline \multirow[t]{10}{*}{ Organic } & Tryptone & $1 \%$ & \\
\hline & & $2 \%$ & $25.7 \pm 0.9$ \\
\hline & & $3 \%$ & $26 \pm 0.8$ \\
\hline & & $4 \%$ & $28.6 \pm 1.2$ \\
\hline & & $5 \%$ & $27.3 \pm 0.4$ \\
\hline & Beef extract & $1 \%$ & $24.3 \pm 1.7$ \\
\hline & & $2 \%$ & $26.3 \pm 0.5$ \\
\hline & & $3 \%$ & $25.7 \pm 0.5$ \\
\hline & & $4 \%$ & $23.6 \pm 1.2$ \\
\hline & & $5 \%$ & $23.6 \pm 1.7$ \\
\hline \multirow[t]{10}{*}{ Inorganic } & Triammonium & $0.1 \%$ & $17.3 \pm 1.2$ \\
\hline & citrate & $0.2 \%$ & $20.3 \pm 1.2$ \\
\hline & & $0.3 \%$ & $22.0 \pm 0.8$ \\
\hline & & $0.4 \%$ & $24.6 \pm 0.9$ \\
\hline & & $0.5 \%$ & $25.7 \pm 1.2$ \\
\hline & Ammonium & $0.1 \%$ & $14.6 \pm 1.2$ \\
\hline & sulphate & $0.2 \%$ & $18.7 \pm 0.4$ \\
\hline & & $0.3 \%$ & $21.3 \pm 1.2$ \\
\hline & & $0.4 \%$ & $24.7 \pm 0.9$ \\
\hline & & $0.5 \%$ & $25.3 \pm 0.4$ \\
\hline Control & - & $27 \pm 1.6$ & \\
\hline
\end{tabular}

Bacteriocin production: Incubation period: $48 \mathrm{~h}$; $\mathrm{pH}: 6$; Incubation temp: $37^{\circ} \mathrm{C}$

Nitrogen sources supplemented in MRS broth (initial $\mathrm{N}_{2}$ sources-1\% Proteose peptone, 1\% Beef extract, $0.5 \%$ yeast extract, $0.2 \%$ ammonium citrate)

Control: CFS of organism grown in initial media (MRS broth) without any nitrogen source supplement.

Well- Diffusion Assay: Well size, mm: 8; Amount of sample used: $100 \mu$ l; Incubation period: $24 \mathrm{~h}$; Incubation temp: $37^{\circ} \mathrm{C}$; Media used: Muller Hinton Agar; $\mathrm{pH}: 7.3 \pm 0.1$.

Indicator strain: B. subtilis

from Enterococcus sp. YT3 confirmed the highest activity with $80 \%$ ammonium sulphate precipitation (Table 11), found to be in coherence with 
Enterococcus faecium LM-2, Enterococcus faecium 3D, Enterococcus faecalis N1-33, Pediococcus pentosaceous NCDC273, Lactobacillus plantarum ZJ5, Lactobacillus sp. MSU3IR ${ }^{11,33,34,35,36,37}$, too. Ammonium sulphate precipitation concentrates the activity of CFS, and is the first step towards the purification of the compounds proteinaceous in nature. It also helps in stability of proteins, reduce proteolysis ${ }^{32}$. This semi purified bacteriocin/ bacteriocin like was subsequently named as Enterocin YT3 (E-YT3).

Table 11: Influence of ammonium sulphate purification on antimicrobial activity

\begin{tabular}{cc}
\hline $\begin{array}{c}\% \text { of Ammonium } \\
\text { sulphate }\end{array}$ & $\begin{array}{c}\text { Zone of inhibition }(\mathrm{mm}) \text { of } \\
\text { Bacillus subtilis }\end{array}$ \\
\hline 30 & $19 \pm 0$ \\
40 & $18.7 \pm 0.9$ \\
50 & $17 \pm 1.4$ \\
60 & $17.3 \pm 0.5$ \\
70 & $19.7 \pm 0.9$ \\
80 & $20.3 \pm 0.5$ \\
\hline
\end{tabular}

For Antibacterial analysis: Well-Diffusion Method (Well size, $\mathrm{mm}$ : 8); Amount of sample used: $100 \mu \mathrm{l}$; Incubation period: $24 \mathrm{~h}$, Incubation temp: $37^{\circ} \mathrm{C}$; Media used: Muller Hinton Agar (Himedia); $\mathrm{pH}: 7.3 \pm 0.1$

\section{Influence of temperature, $\mathrm{pH}$ and enzymes on antibacterial activity}

Effect of temperature: Enterocin YT3, when exposed to different temperatures reported no absolute loss in the anti-bacterial activity, illustrating its thermo-stability at all exposed temperatures (Table 12). Similar thermal stability have been found with enterocins of Enterococcus faecium S6 and R9 and, Enterococcus faecium LR/6 38, 39. Loss in antimicrobial activity was reported for bacteriocins by Enterococcus faecium CK21 and Lactobacillus fermentum PP17 when subjected at $120^{\circ} \mathrm{C}^{40}$.

Table 12: Characterisation of partially purified bacteriocin of Enterococcus sp. YT3

\begin{tabular}{ccccccc}
\hline S. No & Temp, ${ }^{\circ} \mathrm{C}$ & ZOI & $\mathrm{pH}$ & ZOI & Enzyme & ZOI \\
\hline 1 & 37 & + & 2 & + & Trypsin & - \\
2 & 60 & + & 4 & ++ & Pepsin & - \\
3 & 80 & + & 5 & ++ & Proteinase $\mathrm{K}$ & - \\
4 & 100 & + & 9 & + & Lysozyme & + \\
5 & 121 & + & 10 & + & $\alpha$-amylase & + \\
6 & Control & + & Control & + & & \\
\hline
\end{tabular}

For antibacterial analysis: Well- Diffusion Method (Well size, $\mathrm{mm}$ : 8); Amount of sample used: $100 \mu \mathrm{l}$; Incubation period: $24 \mathrm{~h}$, Incubation temp: $37^{\circ} \mathrm{C}$; Media used: Muller Hinton Agar (Himedia); $\mathrm{pH}: 7.3 \pm 0.1$.

+: Activity Present -: Activity Absent
Effect of pH: The biological potential of bacteriocin, as produced by Enterococcus sp. YT3 was retained over wide $\mathrm{pH}$ range (Table 12), though activity was lesser at extremes of $\mathrm{pH}$ tested $(\mathrm{pH} 2$ and 10). $\mathrm{pH}$ stability of bacteriocin finding for different Enteroccocus sp. like, Enterococcus faecium IM 1 and Enterococcus hirae IM1 ${ }^{41}$.

Effect of enzymes: When bacteriocins of Enterococcus sp. YT3 was exposed to variable enzymes, the anti-bacterial activity was completely lost with proteolytic enzymes such as trypsin, proteinase $\mathrm{K}$, and pepsin, depicting proteinaceous moiety of the enterocins because of their digestion with the enzymes. No loss of antimicrobial activity was found when treated with $\alpha$-amylase presenting the non-carbohydrate nature of the Enterocin YT3 (Table 12), as in agreement with other bacteriocin producers as well ${ }^{39,41,42}$.

\section{Determination of protein molecular weight}

On subjecting Enterocin YT3 to SDS PAGE analysis, a single band was found between $35 \mathrm{KDa}$ and $48 \mathrm{KDa}$ (near to $48 \mathrm{KDa}$ ), when compared to the standard markers, as also supported by the fact that the bacteriocins exhibit wide range $(40-5.60 \mathrm{kDa}$ to $10.00-45.00 \mathrm{kDa}$ ) of molecular weights ${ }^{11,43,44}$.

\section{Antimicrobial potential towards selected food pathogens}

Enterocin YT3 produced by Enterococcus sp. YT3 possessed wide range of biological potential (Table 13).

Undiluted Enterocin YT3 was effective against Gram-positive (L. monocytogenes, $S$, aureus and $B$. subtilis) and Gram-negative ( $P$. aeruginosa and $E$. coli $)$. As the bacteriocin preparation was diluted ( $50 \%$ dilution), the activity was lost against L. monocytogenes, but zone of inhibition were found against the other four indicator strains. Except for $S$. aureus, no other test organism was sensitive to any further dilutions. S. aureus was inhibited even at $75 \%$ dilution, indicating to be the most sensitive bacterial strain towards Enterocin YT3. Although, the bacteriocins are generally effective against gram positive organisms, few LAB strains, particularly enterocins has been reported to possess wide spectrum of antimicrobial activity ${ }^{18,45,46}$.

The selected indicator strains (E. coli, $P$. aeruginosa, L. monocytogenes, $S$, aureus and B. subtilis) are most potent contaminants of different food $^{47}$ and were interestingly, found to be sensitive to Enterocin YT3, indicating great potential of Enterocin YT3 in improving shelf life of foods. 
Table 13: Antibacterial data of different dilutions of Enterocin YT3

\begin{tabular}{|c|c|c|c|}
\hline S. No & $\begin{array}{l}\text { Dilutions of } \\
\text { PPB (v/v) }\end{array}$ & Test Organism & $\begin{array}{l}\text { Enterococcus sp. } \\
\text { YT3 ZOI (mm) }\end{array}$ \\
\hline \multirow[t]{5}{*}{1} & $100 \%$ & E. coli & $17.7 \pm 0.9$ \\
\hline & (No dilution) & P. aeruginosa & $20.3 \pm 0.5$ \\
\hline & & S. aureus & $17 \pm 0$ \\
\hline & & Bacillus subtilis & $20.3 \pm 1.2$ \\
\hline & & L. monocytogenes & $14.7 \pm 0.9$ \\
\hline \multirow[t]{4}{*}{2} & $50 \%$ & E. coli & $16.7 \pm 2.3$ \\
\hline & & $\begin{array}{l}\text { P. aeruginosa } \\
\text { S. aureus }\end{array}$ & $\begin{array}{c}14.3 \pm 0.5 \\
13 \pm 0\end{array}$ \\
\hline & & Bacillus subtilis & $14.3 \pm 0.5$ \\
\hline & & L. monocytogenes & Nil \\
\hline \multirow[t]{5}{*}{3} & $75 \%$ & E. coli & Nil \\
\hline & & $P$. aeruginosa & Nil \\
\hline & & S. aureus & $10.3 \pm 0.5$ \\
\hline & & Bacillus subtilis & Nil \\
\hline & & L. monocytogenes & Nil \\
\hline \multirow[t]{5}{*}{4} & $87.5 \%$ & E. coli & Nil \\
\hline & & $P$. aeruginosa & Nil \\
\hline & & S. aureus & Nil \\
\hline & & Bacillus subtilis & Nil \\
\hline & & L. monocytogenes & Nil \\
\hline \multirow[t]{5}{*}{5} & $90 \%$ & E. coli & Nil \\
\hline & & $P$. aeruginosa & Nil \\
\hline & & S. aureus & Nil \\
\hline & & Bacillus subtilis & Nil \\
\hline & & L. monocytogenes & Nil \\
\hline \multirow[t]{5}{*}{6} & $95 \%$ & E. coli & Nil \\
\hline & & $P$. aeruginosa & Nil \\
\hline & & S. aureus & Nil \\
\hline & & Bacillus subtilis & Nil \\
\hline & & L. monocytogenes & Nil \\
\hline \multirow[t]{5}{*}{7} & $99 \%$ & E. coli & Nil \\
\hline & & $P$. aeruginosa & Nil \\
\hline & & S. aureus & Nil \\
\hline & & Bacillus subtilis & Nil \\
\hline & & L. monocytogenes & Nil \\
\hline
\end{tabular}

-Well-Diffusion assay: Well size, mm: 8; Sample: 100 l; Incubation time: $24 \mathrm{~h}$, Incubation temp: $37^{\circ} \mathrm{C}$; Media: Muller Hinton Agar; $\mathrm{pH}$ : 7.3 \pm 0.1 , For L. monocytogenes: Listeria selective agar; $\mathrm{pH}: 7.3 \pm 0.2$. - Dilutions of PPB has been prepared in 0.02M Acetic acid - Nil: no activity observed

\section{CONCLUSION}

Enterococcus sp. YT3, obtained from Indian homemade curd sample, was found to possess significant bacteriocin/bacteriocin like compound producing potential, produced under optimized (MRS broth supplemented $2 \%$ fructose and $4 \%$ tryptone, adjusted to $\mathrm{pH} 6.0$, incubation at $37^{\circ} \mathrm{C}$ for 48 hours). The antimicrobial activity of Enterocin YT3, as indicated by ZOI was very effective against the selected indicator bacterial strain, the maximum protein was concentrated at $80 \%$ ammonium sulphate precipitation, and the antimicrobial peptide was found to be of molecular weight in the range of 35-48 KDa. As food borne diseases are a major global concerns, with huge quantities of food being wasted, or lost before it reaches the consumers ${ }^{48,49}$, bacteriocins provide a promising solution to safeguard food from bacterial contamination. The authors are further involved in investigating Enterococcus sp. YT3 as a source of bacteriocins to be used in food preservation.

\section{ACKNOWLEDGEMENT}

The first author is thankful to Lovely Professional University, Punjab, for providing financial and infrastructural facilities for conducting the research and support at all levels.

\section{Conflict of Interests}

The authors declare that there is no conflict of interests regarding the publication of this paper.

\section{REFERENCES}

1. Cleveland, J.; Montville, T. J.; Nes, I. F.; Chikindas, M. L. Bacteriocins: safe, natural antimicrobials for food preservation. Int. J. Food Microbio., 2001, 71(1), 1-20.

2. Moreno, M.F.; Sarantinopoulos, P.; Tsakalidou, E.; De Vuyst, L. The role and application of enterococci in food and health. Int. J. Food Microbio., 2006, 106(1), 1-24.

3. Khan, H.; Flint, S.; Yu, P. L. Enterocins in food preservation. Int $J$ food microbio., 2010 , 141(1-2), 1-10.

4. Hugas, M.; Garriga, M.; Aymerich, M.T. Functionalty of enterococci in meat products. Int. J Food Microbio., 2003, 88(2-3), 223-33.
5. Javed, A.; Masud, T.; UI Ain, Q.; Imran Maqsood, S. Enterocins of Enterococcus faecium, emerging natural food preservatives. Annals of Microbio., 2011, 61(4), 699-708.

6. Stevens, K.A.; Sheldon, B.W.; Klapes, N.A.; Klaenhammer, T.R. Nisin treatment for inactivation of Salmonella species and other Gram-negative bacteria. Appl. Environ. Microbiol., 1991, 57(12), 3613-5.

7. Balciunas, E.M.; Martinez, F.A.; Todorov, S.D.; de Melo Franco, B.D.; Converti, A.; de Souza Oliveira, R.P. Novel biotechnological applications of bacteriocins: A Review. Food Control., 2013, 32(1), 134-42. 
8. Devriese, L.A.; Van de Kerckhove, A.; KilpperBälz, R.; Schleifer, K.H. Characterization and identification of Enterococcus species isolated from the intestines of animals. Int. J. Sys. Evol. Microbio., 1987, 37(3), 257-9.

9. Facklam, R.R.; Recognition of group D streptococcal species of human origin by biochemical and physiological tests. Appl. Environ. Microbiol., 1972, 23(6), 1131-9.

10. Facklam, R.R.; Collins, M.D. Identification of Enterococcus species isolated from human infections by a conventional test scheme. $J$. Clinic. Microbio., 1989, 27(4), 731-4.

11. lyapparaj, P.; Maruthiah, T.; Ramasubburayan, R.; Prakash, S.; Kumar, C.; Immanuel, G.; Palavesam, A. Optimization of bacteriocin production by Lactobacillus sp. MSU3IR against shrimp bacterial pathogens. Aq. Biosys., 2013, 9, 12.

12. Kaur, D. J.; Arora, D. S. Antibacterial and phytochemical screening of Anethum graveolens, Foeniculum vulgare and Trachyspermum ammi. BMC Compl Alt Med., 2009, 9(1), 30

13. Rana, K. Purification and characterization of bacteriocin(s) of enterococcus spp. obtained from fermented foods of Himachal Pradesh. Phd thesis, Chaudhary Sarwan Kumar Himachal Pradesh Krishi Vishvavidyalaya Palampur-176062 (H.P.) India

14. Yang, E.; Fan, L.; Jiang, Y.; Doucette, C.; Fillmore, S. Antimicrobial activity of bacteriocin producing lactic acid bacteria isolated from cheeses and yogurts. $A M B$ Exp., 2012, 2, 48.

15. Todorov, S.D. Bacteriocin production by Lactobacillus plantarum AMA-K isolated from Amasi, a Zimbabwean fermented milk product and study of the adsorption of bacteriocin AMA-K to Listeria sp. Bra. J. Microbio., 2008, 39(1), 178-87.

16. Todorov, S.D.; Mollendorff, J.W.V.; Dicks, L. M. T. Optimization Of Growth Medium For Production Of Bacteriocins Produced By Lactobacillus Plantarum Jw3bz And Jw6bz, And Lactobacillus Fermentum Jw11bz And Jw15bz Isolated From Boza. Trakia J. Sci., 2009, 7(1), 22-33.

17. Gupta, A.; Tiwari, S. K. Probiotic potential of bacteriocin-producing Enterococcus hirae strain LD3 isolated from dosa batter. Annals of microbio., 2015, 65(4), 2333-42.

18. Line, J. E.; Svetoch, E. A.; Eruslanov, B. V.; Perelygin, V. V.; Mitsevich, E. V.; Mitsevich, I. P.; Levchuk, V. P.; Svetoch, O. E.; Seal, B. S.; Siragusa, G. R.; Stern, N. J. Isolation and purification of enterocin E-760 with broad antimicrobial activity against Gram-positive and Gram-negative bacteria. Antimicro Agents Chemo., 2008, 52(3), 1094-100.

19. Abdel-Haliem, M. E.; Tartour, E.; Enan, G. Characterization, Production and Partial Purification of a Bacteriocin Produced by Lactobacillus plantarum LPS10 Isolated from Pickled Olives. Res. J. Pharm. Bio. Chem. Sci., 2016, 7(5), 2362-71.

20. Behera, S. S.; Ray, R. C.; Zdolec, N. Lactobacillus plantarum with Functional Properties: An Approach to Increase Safety and Shelf-Life of Fermented Foods. Biomed Res Int., 2018, 1-18.

21. Zamfir, M.; Callewaert, R.; Cornea, P. C.; De Vuyst, L. Production kinetics of acidophilin 801 , a bacteriocin produced by Lactobacillus acidophilus IBB 801. FEMS Microbio. Let., 2000, 190(2), 305-8.

22. Ogunbanwo, S. T.; Sanni, A. I.; Onilude, A. A. Influence of cultural conditions on the production of bacteriocin by Lactobacillus brevis OG1. Afr. J. Biotech., 2003, 2(7), 179-84.

23. Rajaram, G.; Manivasagan, P.; Thilagavathi, B.; Saravanakumar, A. Purification and characterization of a bacteriocin produced by Lactobacillus lactis isolated from marine environment. Adv. J. Food Sci. Technol., 2010, 2(2), 138-44.

24. Nithya, K.; Senbagam, D.; Senthilkumar, B.; Udhayashree, N.; Gurusamy, R. Characterization of bacteriocin producing lactic acid bacteria and its application as a food preservative. Afr. J. Microbio. Res., 2012, 6(6), 1138-46.

25. Aguilar-Galvez, A.; Guillermo, S.; DuboisDauphin, R.; Campos, D.; Thonart, P. The influence of growth conditions on enterocin-like production by Enterococcus faecium CWBIB1430 and Enterococcus mundtii CWBI-B1431 isolates from artisanal Peruvian cheeses. Annals Microbio., 2011, 61(4), 955-64. 
26. Yusuf, M. A.; Abdul Hamid, T. H. Optimization of temperature and $\mathrm{pH}$ for the growth and bacteriocin production of Enterococcus faecium B3L3. J. Pharm., 2012, 2(6), 49-59.

27. Abbasiliasi, S.; Tan, J. S.; Ibrahim, T. A.; Bashokouh, F.; Ramakrishnan, N. R.; Mustafa, S.; Ariff, A. B. Fermentation factors influencing the production of bacteriocins by lactic acid bacteria: A Review. RSC Advances., 2017, 7(47), 29395-420.

28. Schirru, S.; Favaro, L.; Mangia, N.P.; Basaglia, M.; Casella, S.; Comunian, R.; Fancello, F.; de Melo Franco, B.D.G.; de Souza Oliveira, R. P.; Todorov, S.D. Comparison of bacteriocins production from Enterococcus faecium strains in cheese whey and optimised commercial MRS medium. Annals of microbiology., 2014, 64(1), 321-331.

29. Mohamed, W. F.; Khalii, K. M. A.; Shady, H. M. A.; Sayed, H. A. E. Activity Range Determination And Optimization Of Various Environmental Conditions For Bacteriocin Production By Lactobacillus Acidophilus and Lactobacillus Plantarum. Egypt. J. Exp. Biol., 2016, 12(1): $53-66$.

30. Drosinos, E. H.; Mataragas, M.; Nasis, P.; Galiotou, M.; Metaxopoulos, J. Growth and bacteriocin production kinetics of Leuconostoc mesenteroides E131. J. App. Microbio., 2005, 99(6), 1314-23.

31. Todorov, S. D.; Danova, S.T.; Van Reenen, C. A.; Meincken, M.; Dinkova, G.; Ivanova, I. V.; Dicks, L. M. Characterization of bacteriocin HV219, produced by Lactococcus lactis subsp. lactis HV219 isolated from human vaginal secretions. J. Bas. Microbio., 2006, 46(3), 226-38.

32. Todorov, S.D.; Dicks, L.M. Influence of growth conditions on the production of a bacteriocin by Lactococcus lactis subsp. lactis ST34BR, a strain isolated from barley beer. J. Bas. Microbio., 2004, 44(4), 305-316.

33. Bayoub, K.; Mardad, I.; Ammar, E.; Serrano, A.; Soukri, A. Isolation and purification of two bacteriocins 3D produced by Enterococcus faecium with inhibitory activity against Listeria monocytogenes. Current microbio., 2011,
62(2), 479-85.

34. Liu, G.; Griffiths, M. W.; Wu, P.; Wang, H.; Zhang, X.; Li, P. Enterococcus faecium LM-2, a multi-bacteriocinogenic strain naturally occurring in "Byaslag", a traditional cheese of Inner Mongolia in China. Food Control., 2011, 22(2), 283-9.

35. Hata, T.; Alemu, M.; Kobayashi. M.; Suzuki, C.; Nitisinprasert, S.; Ohmomo, S. Characterization of a bacteriocin produced by Enterococcus faecalis $\mathrm{N} 1-33$ and its application as a food preservative. J. Food Protec., 2009, 72(3), 524-30.

36. Song, D. F.; Zhu, M. Y.; Gu, Q. Purification and characterization of plantaricin ZJ5, a new bacteriocin produced by Lactobacillus plantarum ZJ5. PLoS One., 2014, 9(8), e105549.

37. Simha, V. B.; Sood, S. K.; Kumariya, R.; Garsa, A. K. Simple and rapid purification of pediocin PA-1 from Pediococcus pentosaceous NCDC 273 suitable for industrial application. Microbio. Res., 2012, 167, 544- 549.

38. Rahmeh, R.; Akbar, A.; Kishk, M.; Al Onaizi, T.; Al-Shatti, A.; Shajan, A.; Akbar, B.; Al-Mutairi, S.; Yateem, A. Characterization of semipurified enterocins produced by Enterococcus faecium strains isolated from raw camel milk. J. Dair. Sci., 2018, 101(6), 4944-52.

39. Kumar, M.;Tiwari, S.K.; Srivastava, S. Purification and characterization of enterocin LR/6, a bacteriocin from Enterococcus faecium LR/6. App Biochem Biotech., 2010, 160(1), 40.

40. Reda, F. M.; Hussein, B. M.; Enan, G. Selection and Characterization of Two Probiotic Lactic Acid Bacteria Strains to be used as Starter and Protective Cultures for Food Fermentations. J. Pure App. Microbio., 2018, 12(3), 1499-513.

41. El-Ghaish, S.; El-Baz, A.; Hwanhlem, N.; Zommara, M.; Ayad, E.; Choiset, Y.; Haertlé, T.; Chobert, J. M. Bacteriocin production and safety evaluation of non-starter Enterococcus faecium IM1 and Enterococcus hirae IM1 strains isolated from homemade Egyptian dairy products. Eur. Food Res. Tech., 2015, 240(6), 1211-23. 
42. Yamamoto, Y.; Togawa, Y.; Shimosaka, M.; Okazaki, M. Purification and characterization of a novel bacteriocin produced by Enterococcus faecalis strain RJ-11. Appl. Environ. Microbiol., 2003, 69(10), 5746-53.

43. Lopez-Lara, I.; Gálvez, A.; Martinez-Bueno, M.; Maqueda, M.; Valdivia E. Purification, characterization, and biological effects of a second bacteriocin from Enterococcus faecalis ssp. liquefaciens S-48 and its mutant strain B-4828. Canad. J. Microbio., 1991, 37(10), 769-74.

44. Nilsen, T.; Nes, I. F.; Holo, H. Enterolysin $A$, a cell wall-degrading bacteriocin from Enterococcus faecalis LMG 2333. Appl. Environ. Microbiol., 2003, 69(5), 2975-84.

45. De Kwaadsteniet, M.; Todorov, S. D.; Knoetze H.; Dicks, L. M. T. Characterization of a 3944 Da bacteriocin, produced by Enterococcus mundtii ST15, with activity against Grampositive and Gram-negative bacteria. Int. J. Food Microbio., 2005, 105, 433-444.

46. Drider, D.; Fimland G.; He'chard, Y.; McMullen, L. M.; Pre'vost. H. The continuing story of class Ila bacteriocins. Microbiol. Mol. Biol. Rev., 2006, 70(2), 564-582.

47. Dave, D.; Ghaly, A. E. Meat spoilage mechanisms and preservation techniques: a critical review. Ame. J. Agri. Bio. Sci., 2011, 6(4), 486-510.

48. Khare, S.; Tonk, A.; Rawat, A. Foodborne diseases outbreak in India: A Review. Int. J. Food Sci. Nutr., 2018, 3(3), 9-10.

49. Anonymous, FAO/WHO, Joint FAO/WHO Food Standards Programme Committee of the Codex Alimentarious Commission, CX/ CAC10/33/15, Geneva., 2010. 